\title{
Conceptuation, formulation and evaluation of sustained release floating tablets of captopril compression coated with gastric dispersible hydrochlorothiazide using $2^{3}$ factorial design
}

\author{
Pathuri Lakshmi Sirisha, Govada Kishore Babu, Puttagunta Srinivasa Babu \\ Department of Pharmaceutics, Vignan Pharmacy College, Vadlamudi, Guntur, Andhra Pradesh, India
}

\begin{abstract}
Ambulatory blood pressure monitoring is regarded as the gold standard for hypertensive therapy in non-dipping hypertension patients. A novel compression coated formulation of captopril and hydrochlorothiazide (HCTZ) was developed in order to improve the efficacy of antihypertensive therapy considering the half-life of both drugs. The synergistic action using combination therapy can be effectively achieved by sustained release captopril $\left(\mathrm{t}_{1 / 2}=2.5 \mathrm{~h}\right)$ and fast releasing HCTZ (average $t_{1 / 2}=9.5 \mathrm{~h}$ ). The sustained release floating tablets of captopril were prepared by using $2^{3}$ factorial design by employing three polymers i.e., ethyl cellulose (EC), carbopol and xanthan gum at two levels. The formulations $\left(\mathrm{CF}_{1}-\mathrm{CF}_{8}\right)$ were optimized using analysis of variance for two response variables, buoyancy and $T_{50 \%}$. Among the three polymers employed, the coefficients and $P$ values for the response variable buoyancy and $T_{50 \%}$ using EC were found to be 3.824 , 0.028 and $0.0196,0.046$ respectively. From the coefficients and $P$ values for the two response variables, formulation $\mathrm{CF}_{2}$ was optimized, which contains $\mathrm{EC}$ polymer alone at a high level. The $\mathrm{CF}_{2}$ formulation was further compression coated with optimized gastric dispersible HCTZ layer $\left(\mathrm{HF}_{9}\right)$. The compression coated tablet was further evaluated using drug release kinetics. The $\mathrm{Q}$ value of HCTZ layer is achieved within 20 min following first order release whereas the $\mathrm{Q}$ value of captopril was obtained at $6.5 \mathrm{~h}$ following Higuchi model, from which it is proved that rapid release HCTZ and slow release of captopril is achieved. The mechanism of drug release was analyzed using Peppas equation, which showed an $n>0.90$ confirming case II transportation mechanism for drug release.
\end{abstract}

Key words: Ambulatory blood pressure monitoring, analysis of variance, compression coating, ethyl cellulose, floating drug delivery, non-dipping

\section{RESEARCH BACKGROUND}

For effective treatment of hypertension combination therapy is mostly prescribed by doctors. Among the drugs that are given in combination hydrochlorothiazide (HCTZ) is used as front line combination drug and it is highly compatible with angiotensin converting enzyme (ACE) inhibitors and angiotensin II receptor

\section{Address for correspondence:}

Dr. G. Kishore Babu

Department of Pharmaceutics, Vignan Pharmacy College,

Vadlamudi, Guntur - 522 002, Andhra Pradesh, India.

E-mail: kishorempharm@gmail.com

\begin{tabular}{|l|l|}
\hline \multicolumn{2}{|c|}{ Access this article online } \\
\hline Quick Response Code: & Website: \\
\hline & www.jpionline.org \\
\cline { 2 - 2 } & DOI: \\
\hline
\end{tabular}

blockers. Most of the ACE inhibitors such as captopril, ramipril and enalapril possess short biological half-life (2-4 h.) whereas HCTZ possesses a biological half-life of 9-14 h. Due to variability in half-lives of drugs the synergistic action of combinational therapy is not achieved.

Considering various types of hypertensive patients as per American Heart Association, ineffective combination therapy could lead to long-term renal and cardiac damages. Therefore, in case of non-dipping patients it is highly essential to maintain drug concentration throughout $24 \mathrm{~h}$. cycle irrespective of circadian pattern.

\section{INTRODUCTION}

Appropriate assessment of clinical blood pressure (CBP) level is the premise for risk stratification and adequate therapeutic strategy with regard to hypertension. CBP is usually just performed in the daytime. CBP is rarely performed 
at night-time in the hospital ward, unless there are acute or severe conditions thereby providing poor information about non-dippers. Many evidences have proved that non-dippers are more favorable in predicting the mortality and morbidity related to dippers. ${ }^{[1,2]}$ Therefore, nocturnal BP should be taken seriously in the hospital setting for every patient, especially for those with abnormal BP. Ambulatory blood pressure monitoring is regarded as the gold standard for monitoring nocturnal BP. According to many suggestions from various clinical trials, $75 \%$ of patients will require combination therapy for effective control of blood pressure. As per the seventh report of Joint National Committee guidelines, combination therapy is suggested as first line treatment for patients with $>20 \mathrm{mmHg}$ systolic and $>10 \mathrm{mmHg}$ diastolic $\mathrm{BP}$ respectively. ${ }^{[3]}$ Combination therapy increases the rate of $\mathrm{BP}$ control and requires less time to reach target $\mathrm{BP}$ with better tolerability than high dose therapy. It has fewer side-effects, better patient compliance and low in cost. ${ }^{[4,5]}$

Captopril ([2S]-1-([2S]-2-methyl-3-sulfanylpropanoyl) pyrrolidine-2-carboxylic acid) is an ACE inhibitor. It affects the rennin-angiotensin system, thereby inhibits the conversion of angiotensin I to angiotensin II. The drug is considered as a drug of choice for the treatment of hypertension ${ }^{[6]}$ and congestive heart failure. ${ }^{[7]}$ The bioavailability of captopril is approximately $60-75 \%$ and it has elimination half-life after an oral dose is $2-3$ h. It is stable at acidic $\mathrm{pH}(1.2)$ and is specifically absorbed from the stomach. As the $\mathrm{pH}$ increases, the drug becomes unstable and undergoes a pseudo first order degradation reaction. ${ }^{[8,9]}$ The drug is susceptible to produce stability problems. ${ }^{[10]}$ In aqueous solutions due to degradation reaction. The drug being freely water soluble suffers from burst effect and also from dose dumping phenomenon when formulated as sustained or controlled formulation. There is a strong prerequisite to localize the developed captopril formulation at the target area of the gastrointestinal tract. ${ }^{[1]}$ To overcome the above drawbacks the present study is aimed at developing a floating dosage form to be remained buoyant in the stomach, thereby, increasing the gastric residence time, stability, patient's compliance and enhancing the bioavailability of drug through sustained release.

HCTZ is a thiazide diuretic. It is used in the management of edema and in patients with lower the blood pressure. It inhibits sodium reabsorption in the distal tubules causing increased excretion of sodium and water as well as potassium and hydrogen ions. HCTZ is poorly water soluble drug having plasma half-life of 6-14 h. ${ }^{[12]}$ HCTZ is only absorbed from the upper part of the duodenum and once it passes this absorption site, little or no absorption takes place. ${ }^{[13]}$ Since the half-life of captopril is very short, the combination of HCTZ which is having a long half-life will render synergistic effect on antihypertensive action.

The present study is aimed at formulation of floating captopril tablets compression coated with gastric dispersible HCTZ layer. The pictorial representation of mechanism of floating of optimized compression coated tablets was shown in Figure 1. In this study, the effort has been made to formulate captopril floating core tablets by using a single polymer, which has a dual action with better release profile of drug and enhancement in buoyancy rate. Screening of polymers has been done to obtain the optimized formulation.

\section{MATERIALS AND METHODS}

Captopril and HCTZ were obtained as a gift sample from Dr. Reddy's Laboratories. Ethyl cellulose (EC) was received from Indian research products. Xanthan gum and carbopol were gifted from Loba Chemie Pvt. Ltd. Lactose was obtained from Chem India. All the other solvents used were of pharmaceutical or analytical grade. Sodium starch glycolate (SSG), croscarmellose sodium and crospovidone were obtained from the Signet Chemicals, Mumbai. All the other solvents used were of pharmaceutical or analytical grade.

\section{EXPERIMENTAL}

\section{Preparation of floating captopril core tablets using $2^{3}$} factorial design

The screening of polymers for optimization of captopril core tablets was carried out by $2^{3}$ factorial designs. The three factors each at two levels, i.e., actual values and coded values were considered as shown in [Table 1]. EC is considered as Factor A', Xanthan gum and carbopol were considered as Factor B and C respectively. "Factor C" was taken as polymer carbopol. A total

\begin{tabular}{|c|c|c|}
\hline Factors & Low level (mg) & High level (mg) \\
\hline Ethyl cellulose (A) & 60 & 130 \\
\hline Xanthan gum (B) & 0 & 5 \\
\hline Carbopol (C) & 0 & 10 \\
\hline
\end{tabular}

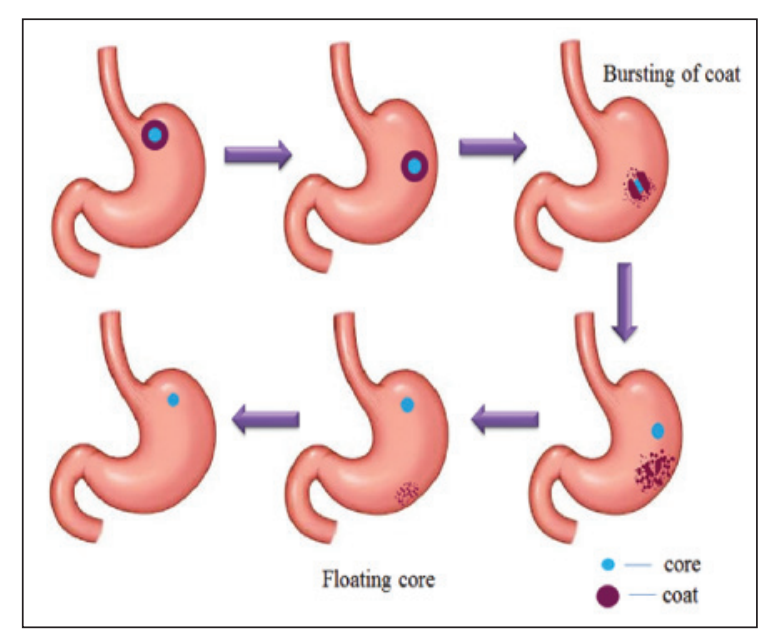

Figure 1: Pictorial representation of mechanism of floating of compression coated tablet 
of eight formulations were obtained according to the model $\left(2^{3}=2 \times 2 \times 2=8\right)$.

Floating tablets containing captopril were prepared by direct compression technique using various polymers. In all formulations, lactose is used as a diluent and talc as a glidant. The composition of various formulations of captopril floating tablets is given in the [Table 2]. All the ingredients along with the drug were weighed accurately, mixed thoroughly and passed through sieve \#60 before processing. Sifting was carried out after addition of each ingredient to ensure uniform mixing. The resultant blend was subjected to direct compression using Elite 10 station rotary tablet compression machine containing round biconcave punches. The prepared tablets of captopril were subjected to various evaluation tests.

Evaluation of floating captopril core tablet formulations Powder blend of captopril formulations was evaluated for various pre-compression parameters such as Bulk Density, Tapped Density, Compressibility index, Hausner's ratio and Angle of repose. The results for all the captopril formulations were shown in [Table 3].

The prepared captopril tablets were subjected to various evaluation tests such as weight variation, hardness and friability tests. The results of all these post-compression characteristics of captopril were shown in [Table 4]. Test for buoyancy was carried out and the results were shown in [Table 5 and Figure 2].

\section{In vitro drug release study}

The in vitro drug release study was performed for the formulation and pure drugs using USP type II dissolution apparatus (paddle type). The samples were withdrawn at regular intervals and are analyzed using ultraviolet (UV) spectrophotometric method at $204.6 \mathrm{~nm}$. The results were shown in [Table 6]. The zero order drug release profiles of all formulations were shown in [Figure 3].

\section{OPTIMIZATION OF $2^{3}$ FACTORIAL DESIGN BY STATISTICAL ANALYSIS}

Multiple regression is a statistical technique that allows us to predict the effect of independent factor on dependent formulation response variables. In $2^{3}$ factorial design, an analysis of variance (ANOVA) was performed for the situation where there are three independent variables, EC (A), Xanthan gum (B) and Carbopol (C), each with two levels (low and high). This design will have $2^{3}=8$ different experimental conditions. Buoyancy and time required for $50 \%$ of drug release were considered as the dependent response variables. After performing 8 runs of formulations, the data obtained for the response variable in all runs was subjected to multiple regression analysis using Microsoft excel 2007 software for statistical assessment. The regression statistics of ANOVA for first response variable, buoyancy are given in [Tables 7 and 8] and that of the second response variable, $\mathrm{T}_{50 \%}$ are given in [Tables 9 and 10] and line fit plots were shown in [Figures 4 and 5] respectively.

\section{FORMULATION OF HCTZ COAT LAYER}

The formulations were prepared using various disintegrants such as SSG, crospovidone and croscarmellose sodium. Pregelatinized starch was added a dry binder. Magnesium stearate was used as a lubricant. Talc was included as a glidant in the formulation. The composition of various formulations containing HCTZ is given in the [Table 11].

\section{Evaluation of HCTZ coat tablet formulations}

Powder blend of HCTZ formulations was evaluated for various pre-compression parameters such as bulk density, tapped density, compressibility index, Hausner's ratio and Angle of repose. The results for all the HCTZ formulations were shown in [Table 12].

\section{Table 2: Composition of captopril floating tablets based on $2^{3}$ factorial design}

\begin{tabular}{|c|c|c|c|c|c|c|c|c|}
\hline Ingredients & $\mathrm{CF}_{1(\mathrm{mg})}$ & $\mathrm{CF}_{2(\mathrm{mg})}$ & $\mathrm{CF}_{3(\mathrm{mg})}$ & $\mathrm{CF}_{4(\mathrm{mg})}$ & $\mathrm{CF}_{5(\mathrm{mg})}$ & $\mathrm{CF}_{6(\mathrm{mg})}$ & $\mathrm{CF}_{7(\mathrm{mg})}$ & $\mathrm{CF}_{8(\mathrm{mg})}$ \\
\hline Drug & 30 & 30 & 30 & 30 & 30 & 30 & 30 & 30 \\
\hline Ethyl cellulose & 60 & 130 & 60 & 130 & 60 & 130 & 60 & 130 \\
\hline Xanthan gum & - & - & 5 & 5 & - & - & 5 & 5 \\
\hline Carbopol & - & - & - & - & 10 & 10 & 10 & 10 \\
\hline Lactose & 100 & 30 & 95 & 25 & 90 & 20 & 85 & 15 \\
\hline Talc & 5 & 5 & 5 & 5 & 5 & 5 & 5 & 5 \\
\hline
\end{tabular}

\section{Table 3: Evaluation of pre-compression characteristics of captopril formulations}

\begin{tabular}{lccccc}
\hline Formulation code & Bulk density $(\mathbf{g} / \mathbf{m l})$ & Tapped density $(\mathbf{g} / \mathbf{m l})$ & Carr's index $(\%)$ & Hausner's ratio & Angle of repose $\left(^{\circ}\right)$ \\
\hline $\mathrm{CF}_{1}$ & 0.175 & 0.243 & 27.98 & 1.39 & 43 \\
$\mathrm{CF}_{2}$ & 0.166 & 0.178 & 13.74 & 1.07 & 26.78 \\
$\mathrm{CF}_{3}$ & 0.336 & 0.453 & 25.82 & 1.35 & 3.36 \\
$\mathrm{CF}_{4}$ & 0.171 & 0.189 & 16.52 & 1.11 & 29.59 \\
$\mathrm{CF}_{5}$ & 0.348 & 0.508 & 1.49 & 1.18 & 40.96 \\
$\mathrm{CF}_{6}$ & 0.175 & 0.206 & 20.65 & 1.26 & 31.85 \\
$\mathrm{CF}_{7}$ & 0.169 & 0.213 & 19.13 & 1.24 & 47.86 \\
$\mathrm{CF}_{8}$ & 0.169 & 0.209 & & & 32.84 \\
\hline
\end{tabular}


The prepared HCTZ tablets were subjected to various evaluation tests such as weight variation, hardness, friability, disintegration, wetting tests. The results of all these post-compression

\begin{tabular}{|c|c|c|c|}
\hline $\begin{array}{l}\text { Formulation } \\
\text { code }\end{array}$ & $\begin{array}{l}\text { Weight variation } \\
(\mathrm{mg})(n=20)\end{array}$ & $\begin{array}{c}\text { Friability } \\
(\%)(n=10)\end{array}$ & $\begin{array}{c}\text { Hardness } \\
\left(\mathrm{kg} / \mathrm{cm}^{2}\right)(n=6)\end{array}$ \\
\hline $\mathrm{CF}_{1}$ & $195 \pm 0.298$ & 1.03 & 3.0 \\
\hline $\mathrm{CF}_{2}^{1}$ & $195 \pm 0.231$ & 0.98 & 3.0 \\
\hline $\mathrm{CF}_{3}^{2}$ & $195 \pm 0.339$ & 1.12 & 2.5 \\
\hline $\mathrm{CF}_{4}^{3}$ & $195 \pm 0.287$ & 1.07 & 2.1 \\
\hline $\mathrm{CF}_{5}^{4}$ & $195 \pm 0.456$ & 1.32 & 1.8 \\
\hline $\mathrm{CF}_{6}^{5}$ & $195 \pm 0.783$ & 1.01 & 2.9 \\
\hline $\mathrm{CF}_{7}^{6}$ & $195 \pm 0.247$ & 0.98 & 2.9 \\
\hline $\mathrm{CF}_{8}^{\prime}$ & $195 \pm 0.334$ & 1.05 & 2.7 \\
\hline
\end{tabular}

\begin{tabular}{lc}
$\begin{array}{l}\text { Table 5: Duration of floatation for various } \\
\text { captopril formulations }\end{array}$ \\
\hline Formulations & Floating time \\
\hline $\mathrm{CF}_{1}$ & $59 \mathrm{~s}$ \\
$\mathrm{CF}_{2}$ & $>8 \mathrm{~h}$ \\
$\mathrm{CF}^{3}$ & 1 min $20 \mathrm{~s}$ \\
$\mathrm{CF}_{4}$ & $6 \mathrm{~h}$, disintegrated \\
$\mathrm{CF}_{5}$ & $55 \mathrm{~s}$ \\
$\mathrm{CF}_{6}$ & $2 \mathrm{~h}$ \\
$\mathrm{CF}_{7}$ & $6 \mathrm{~min}$ \\
$\mathrm{CF}_{8}$ & $2 \mathrm{~h}$ \\
\hline
\end{tabular}

characteristics of captopril were shown in [Table 13]. Comparison of disintegration time of various HCTZ formulations was shown in [Figure 6].

\section{In vitro drug release study}

The in vitro drug release study was performed for the formulation and pure drugs using USP type II dissolution apparatus (paddle type). The samples were withdrawn at regular intervals and are analyzed using UV spectrophotometric method at $217.6 \mathrm{~nm}$. The results were shown in [Table 14].

The zero order plot of all HCTZ formulations was shown in [Figure 7].

\section{FORMULATION OF COMPRESSION COATED TABLETS}

The optimized formulations of captopril core and HCTZ coat layers were chosen for formulation of compression coated tablet. The required weight of the captopril powder blend mixed with all other ingredients $(195 \mathrm{mg}$ ) was weighed and transferred into small die and compressed as core tablets. In the second step, a slightly larger die of $13 \mathrm{~mm}$ diameter was partially filled with half of the HCTZ coat material $(275.5 \mathrm{mg})$ and then captopril core tablet was manually

Table 6: In vitro drug release data of captopril formulations

\begin{tabular}{|c|c|c|c|c|c|c|c|c|}
\hline \multirow[t]{2}{*}{ Time (h) } & \multicolumn{8}{|c|}{$\%$ drug release of formulations } \\
\hline & $\mathrm{CF}_{1}$ & $\mathrm{CF}_{2}$ & $\mathrm{CF}_{3}$ & $\mathrm{CF}_{4}$ & $\mathrm{CF}_{5}$ & $\mathrm{CF}_{6}$ & $\mathrm{CF}_{7}$ & $\mathrm{CF}_{8}$ \\
\hline 0.25 & $15.48 \pm 1.32$ & $8.451 \pm 1.77$ & $11.34 \pm 1.34$ & $14.85 \pm 1.63$ & $14.98 \pm 1.41$ & $11.67 \pm 1.37$ & $15.76 \pm 1.35$ & $15.26 \pm 1.36$ \\
\hline 0.5 & $23.92 \pm 1.81$ & $12.26 \pm 1.97$ & $16.87 \pm 1.73$ & $19.03 \pm 1.95$ & $26.75 \pm 1.38$ & $19.45 \pm 1.29$ & $21.69 \pm 1.76$ & $22.46 \pm 1.67$ \\
\hline 1 & $30.14 \pm 1.45$ & $19.92 \pm 1.94$ & $23.10 \pm 1.29$ & $28.46 \pm 1.56$ & $38.69 \pm 1.82$ & $28.04 \pm 1.82$ & $36.90 \pm 1.90$ & $31.73 \pm 0.103$ \\
\hline 2 & $49.56 \pm 1.73$ & $28.54 \pm 1.76$ & $39.05 \pm 1.31$ & $36.21 \pm 1.73$ & $48.92 \pm 1.24$ & $41.46 \pm 1.39$ & $48.93 \pm 1.43$ & $40.74 \pm 1.27$ \\
\hline 3 & $62.53 \pm 1.67$ & $36.17 \pm 161$ & $49.87 \pm 1.87$ & $44.05 \pm 1.89$ & $56.39 \pm 1.73$ & $52.69 \pm 1.68$ & $55.35 \pm 1.75$ & $49.38 \pm 1.83$ \\
\hline 4 & $81.90 \pm 1.28$ & $45.43 \pm 1.94$ & $54.78 \pm 1.58$ & $62.60 \pm 1.68$ & $61.18 \pm 1.96$ & $61.48 \pm 1.49$ & $62.86 \pm 1.96$ & $54.67 \pm 1.24$ \\
\hline 5 & $86.34 \pm 1.21$ & $61.26 \pm 1.99$ & $59.64 \pm 1.46$ & $79.48 \pm 1.61$ & $67.67 \pm 1.21$ & $70.27 \pm 1.46$ & $69.47 \pm 1.31$ & $65.08 \pm 1.62$ \\
\hline 6 & - & $74.41 \pm 1.83$ & $65.08 \pm 1.93$ & $89.97 \pm 1.83$ & $71.47 \pm 1.03$ & $75.36 \pm 1.32$ & $75.73 \pm 1.37$ & $72.92 \pm 1.59$ \\
\hline 7 & - & $90.37 \pm 1.84$ & $73.36 \pm 1.82$ & - & $75.68 \pm 1.74$ & $78.45 \pm 1.78$ & $79.98 \pm 1.87$ & $79.56 \pm 1.92$ \\
\hline 8 & & $97.42 \pm 1.45$ & $77.34 \pm 1.68$ & - & $77.02 \pm 1.87$ & $84.42 \pm 1.94$ & $81.87 \pm 1.62$ & $82.36 \pm 1.71$ \\
\hline
\end{tabular}

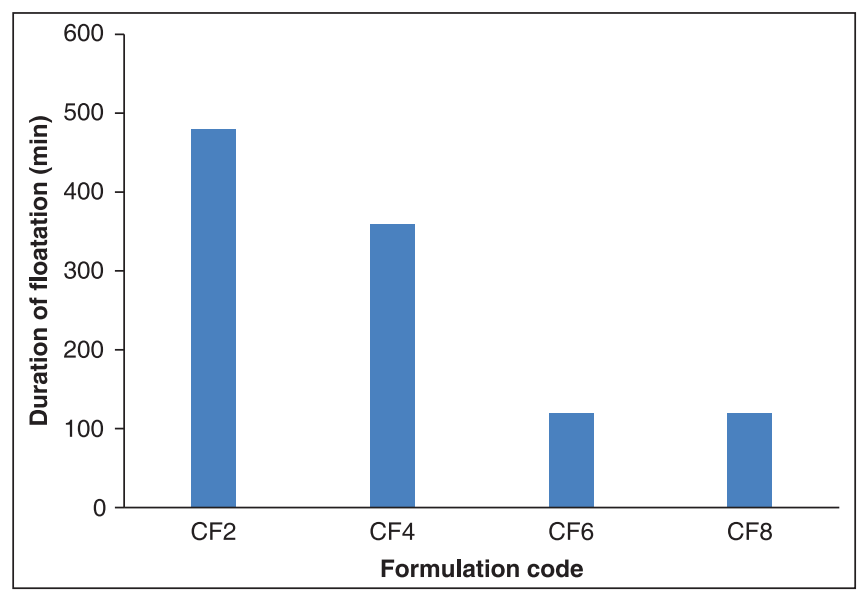

Figure 2: Comparison of floating times of various formulations

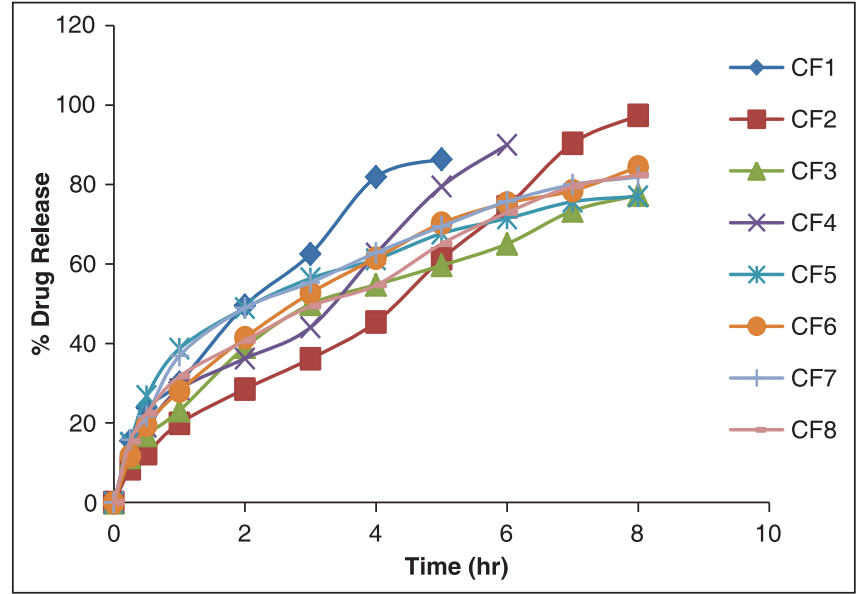

Figure 3: Zero order plot of captopril formulations 
Table 7: Estimation of significance factor of analysis of variance for response of buoyancy

\begin{tabular}{lccccc}
\hline Source & df & SS & MS & $\boldsymbol{F}$ & $\begin{array}{c}\text { Significance } \\
\boldsymbol{F}\end{array}$ \\
\hline Regression & 3 & 189256.8 & 63085.61 & 4.920105 & 0.078916 \\
Residual & 4 & 51288.02 & 12822.01 & & \\
Total & 7 & 240544.9 & & & \\
\hline
\end{tabular}

Table 8: Estimation of regression coefficient of analysis of variance for response of buoyancy

\begin{tabular}{lccc}
\hline Factor & Coefficients & Standard error & $\boldsymbol{P}$ value \\
\hline Intercept & 1.571429 & 0.779398 & 0.113989 \\
Ethyl cellulose & 0.019643 & 0.006916 & 0.046859 \\
Xanthan gum & -0.025 & 0.096825 & 0.808994 \\
Carbopol & -0.0875 & 0.048412 & 0.144986 \\
\hline
\end{tabular}

Table 9: Estimation of significance factor of analysis of variance for response of $T_{50}$

\begin{tabular}{lccccc}
\hline Source & df & SS & MS & $\boldsymbol{F}$ & Significance $\boldsymbol{F}$ \\
\hline Regression & 3 & 5.34375 & 1.78125 & 3.8 & 0.114947 \\
Residual & 4 & 1.875 & 0.46875 & & \\
Total & 7 & 7.21875 & & & \\
\hline
\end{tabular}

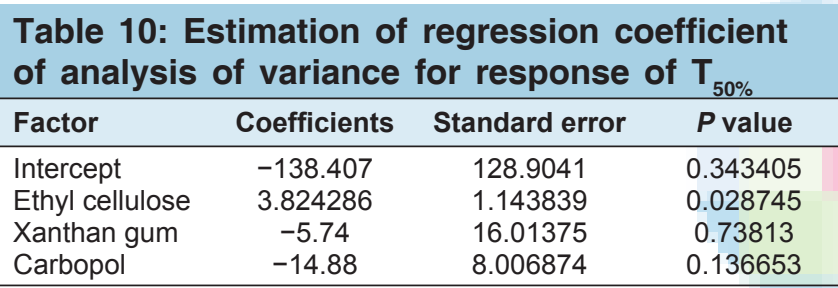

placed centrally and the remaining HCTZ coat material $(275.5 \mathrm{mg}$ ) was filled on the top of the captopril core and finally compression force was applied using Elite-10 station GMP model rotary press with round biconcave punches resulting in tablet within tablet (compression/press coated tablet). The images of compression coated formulation were shown in [Figure 8].

\section{EVALUATION OF COMPRESSION COATED TABLETS}

After the compression of core tablet with coat layer, the postcompression parameters would change. So the compression coated tablets were subjected to various evaluation tests. The results of weight variation, friability, hardness, disintegration of coat, thickness, wetting time and water absorption ratio were given in [Table 15].

\section{In vitro drug release study}

The optimized formulation was evaluated for drug release study using USP type II dissolution apparatus (paddle type). A total volume of $5 \mathrm{ml}$ sample solution was withdrawn from the dissolution apparatus at regular time intervals and the sample solution was replaced with fresh dissolution medium to maintain sink conditions. The samples were withdrawn at regular intervals of at 5, 10, 15, 20 and $25 \mathrm{~min}$ for HCTZ and at $0.25,0.5,1,2,3,4,5,6,7$ and $8 \mathrm{~h}$. for the captopril. The sample solutions were filtered through $0.45 \mu \mathrm{m}$ Whattman filter paper and analyzed using UV spectrophotometric method at 204.6 $\mathrm{nm}$ for captopril and $271.6 \mathrm{~nm}$ for HCTZ. The kinetic models used were a zero order equation, first order, Higuchi release

Table 11: Various formulations of hydrochlorothiazide coat layer

\begin{tabular}{lccccccccc}
\hline Material (weight in $\mathbf{m g}$ ) & $\mathbf{F}_{\mathbf{1}}$ & $\mathbf{F}_{\mathbf{2}}$ & $\mathbf{F}_{\mathbf{3}}$ & $\mathbf{F}_{\mathbf{4}}$ & $\mathbf{F}_{\mathbf{5}}$ & $\mathbf{F}_{\mathbf{6}}$ & $\mathbf{F}_{\mathbf{7}}$ & $\mathbf{F}_{\mathbf{8}}$ & $\mathbf{F}_{\mathbf{9}}$ \\
\hline Hydrochlorothiazide & 12 & 12 & 12 & 12 & 12 & 12 & 12 & 12 & 12 \\
SSG & 27.75 & - & - & 55.5 & - & - & 83.25 & - \\
Crospovidone & - & 27.75 & - & - & 55.5 & - & - & - \\
Croscarmellose sodium & - & - & 27.75 & - & - & 55.5 & - & - \\
MCC & 495.25 & 495.25 & 495.25 & 467.5 & 467.5 & 467.5 & 439.75 & 439.75 & 43.25 \\
Pregelatinized starch & 10 & 10 & 10 & 10 & 10 & 10 & 10 & 10 & 10 \\
Magnesium stearate & 5 & 5 & 5 & 5 & 5 & 5 & 5 & 5 \\
Talc & 5 & 5 & 5 & 5 & 5 & 5 & 5 & 5 \\
\hline
\end{tabular}

SSG: Sodium starch glycolate, MCC: Microcrystalline cellulose
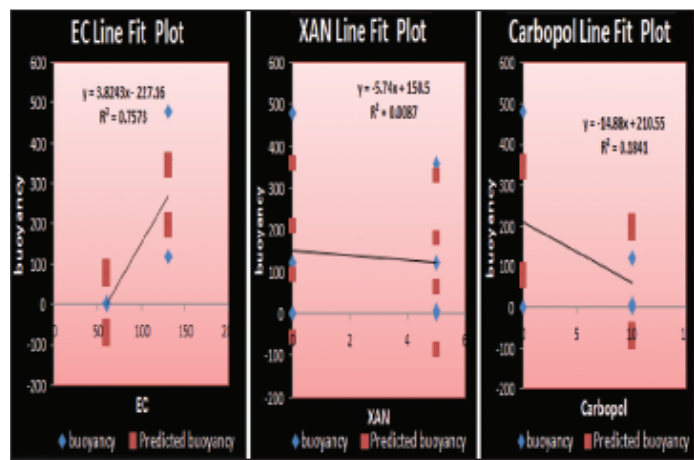

Figure 4: Line fit plots for response of buoyancy
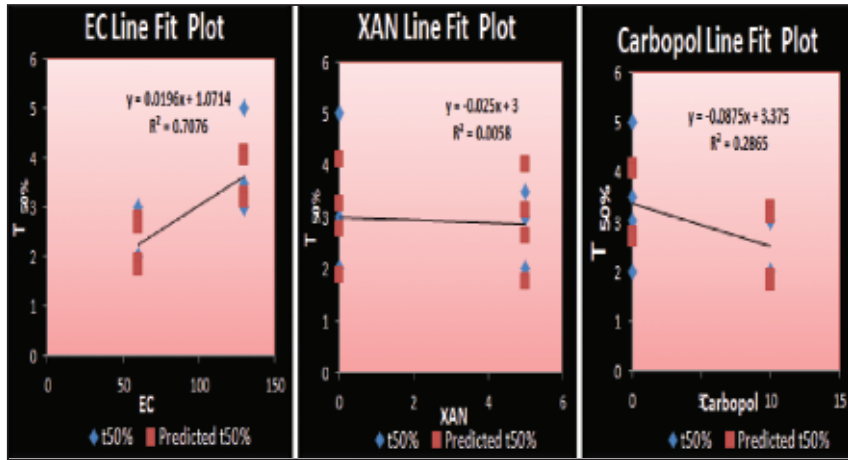

Figure 5: Line fit plots for the response of T50\% 
and Korsmeyer-Peppas models. [Table 16] shows correlation coefficients of the formulation.

\section{Estimation of drug content}

A total of 20 tablets from each batch were crushed in mortar and the powder equivalent to $100 \mathrm{mg}$ each of captopril and HCTZ

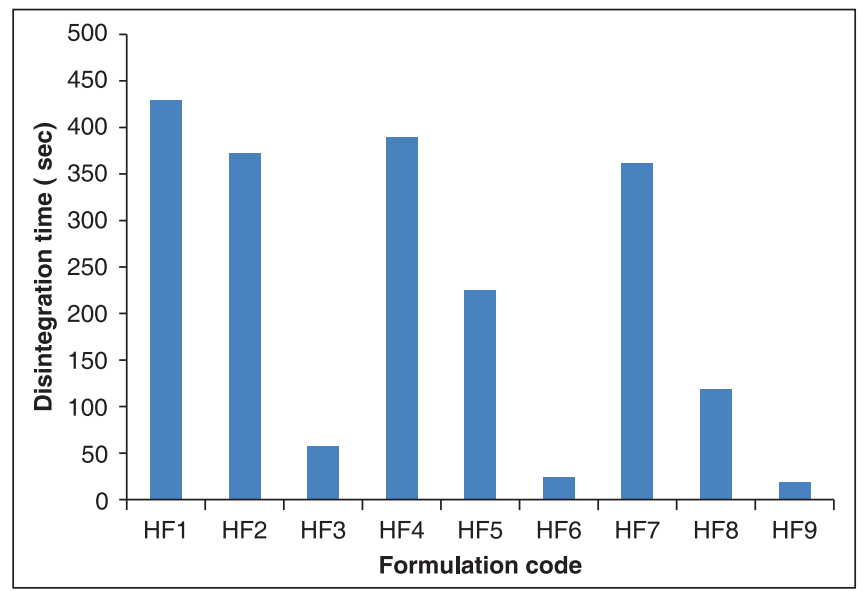

Figure 6: Comparison of disintegration time of various hydrochlorothiazide formulations was shaken with $100 \mathrm{ml}$ of $0.1 \mathrm{~N} \mathrm{Hcl}$ in a $100 \mathrm{ml}$ volumetric flask and sonicated for $15 \mathrm{~min}$ and filtered through $0.45 \mu \mathrm{m}$ Whatman filter paper. After necessary dilutions, sample was measured at $271.6 \mathrm{~nm}$ for HCTZ and $204.6 \mathrm{~nm}$ for captopril using UV-visible spectrophotometer and the results were shown in [Table 17].

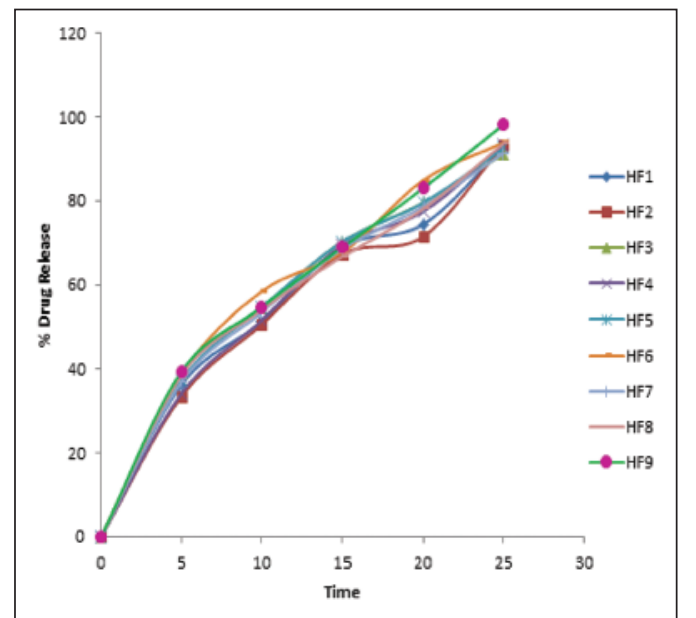

Figure 7: Zero order plot of all hydrochlorothiazide formulations

\section{Table 12: Evaluation of pre-compression characteristics of hydrochlorothiazide formulations}

\begin{tabular}{lccccc}
\hline Formulation code & Bulk density $(\mathbf{g} / \mathbf{m l})$ & Tapped density $(\mathbf{g} / \mathbf{m l})$ & Carr's index $(\%)$ & Hausner's ratio & Angle of repose $\left(^{\circ}\right)$ \\
\hline $\mathrm{HF}_{1}$ & 0.431 & 0.523 & 17.6 & 1.21 & 39.84 \\
$\mathrm{HF}_{2}$ & 0.424 & 0.520 & 18.5 & 1.23 & 3.91 \\
$\mathrm{HF}_{3}$ & 0.428 & 0.524 & 18.3 & 1.22 & 3.23 \\
$\mathrm{HF}^{3}$ & 0.425 & 0.523 & 18.7 & 1.24 & 39.32 \\
$\mathrm{HF}_{5}$ & 0.420 & 0.528 & 20.5 & 1.21 & 37.45 \\
$\mathrm{HF}_{6}$ & 0.432 & 0.521 & 20.4 & 1.24 & 33.67 \\
$\mathrm{HF}_{7}$ & 0.420 & 0.528 & 15.9 & 1.19 & 37.32 \\
$\mathrm{HF}^{8}$ & 0.438 & 0.521 & 14.53 & 1.17 & 34.89 \\
$\mathrm{HF}_{9}$ & 0.441 & 0.516 & & & 33.26 \\
\hline
\end{tabular}

\section{Table 13: Evaluation of post-compression characteristics of hydrochlorothiazide formulations}

\begin{tabular}{|c|c|c|c|c|c|c|}
\hline $\begin{array}{l}\text { Formulation } \\
\text { code }\end{array}$ & $\begin{array}{l}\text { Weight variation } \\
(\mathrm{mg})(n=20)\end{array}$ & $\begin{array}{l}\text { Friability (\%) } \\
\quad(n=10)\end{array}$ & $\begin{array}{c}\text { Hardness } \\
\left(\mathrm{kg} / \mathrm{cm}^{2}\right)(n=6)\end{array}$ & $\begin{array}{l}\text { Thickness } \\
(\mathrm{mm})(n=6)\end{array}$ & $\begin{array}{l}\text { Disintegration } \\
\text { time (s) }\end{array}$ & Wetting time (s) \\
\hline $\mathrm{HF}_{1}$ & $555 \pm 1.29$ & 0.93 & $3.1 \pm 0.5$ & $3.9 \pm 0.5$ & 429 & 12 \\
\hline $\mathrm{HF}_{2}^{1}$ & $555 \pm 1.32$ & 0.88 & $3.1 \pm 0.5$ & $3.9 \pm 0.5$ & 372 & 10.58 \\
\hline $\mathrm{HF}_{3}^{2}$ & $555 \pm 1.27$ & 0.82 & $2.9 \pm 0.5$ & $3.9 \pm 0.5$ & 58 & 9.34 \\
\hline $\mathrm{HF}_{4}^{3}$ & $555 \pm 1.26$ & 0.92 & $2.9 \pm 0.5$ & $3.8 \pm 0.5$ & 390 & 10.89 \\
\hline $\mathrm{HF}_{5}^{4}$ & $555 \pm 1.34$ & 0.94 & $2.8 \pm 0.5$ & $3.9 \pm 0.5$ & 225 & 9.56 \\
\hline $\mathrm{HF}_{6}^{5}$ & $555 \pm 1.23$ & 0.82 & $2.9 \pm 0.5$ & $3.8 \pm 0.5$ & 24 & 8.63 \\
\hline $\mathrm{HF}_{7}^{6}$ & $555 \pm 1.29$ & 0.98 & $2.9 \pm 0.5$ & $3.4 \pm 0.5$ & 362 & 9.89 \\
\hline $\mathrm{HF}_{8}^{7}$ & $555 \pm 1.28$ & 0.83 & $3.0 \pm 0.5$ & $3.8 \pm 0.5$ & 119 & 7.63 \\
\hline $\mathrm{HF}_{9}^{8}$ & $555 \pm 1.26$ & 0.78 & $3.0 \pm 0.5$ & $3.5 \pm 0.5$ & 19 & 6.12 \\
\hline
\end{tabular}

Table 14: In vitro drug release data of hydrochlorothiazide formulations

\begin{tabular}{|c|c|c|c|c|c|c|c|c|c|}
\hline \multirow{2}{*}{$\begin{array}{l}\text { Time } \\
(\min )\end{array}$} & \multicolumn{9}{|c|}{$\%$ drug release } \\
\hline & $\mathrm{HF}_{1}$ & $\mathrm{HF}_{2}$ & $\mathrm{HF}_{3}$ & $\mathrm{HF}_{4}$ & $\mathrm{HF}_{5}$ & $\mathrm{HF}_{6}$ & $\mathrm{HF}_{7}$ & $\mathrm{HF}_{8}$ & $\mathrm{HF}_{9}$ \\
\hline 5 & $36.25 \pm 0.73$ & $33.50 \pm 0.78$ & $39.05 \pm 0.87$ & $34.23 \pm 0.38$ & $37.34 \pm 0.87$ & $38.82 \pm 1.11$ & $36.93 \pm 0.72$ & $38.57 \pm 1.12$ & $39.46 \pm 0.87$ \\
\hline 10 & $51.32 \pm 0.94$ & $50.65 \pm 0.57$ & $54.56 \pm 0.94$ & $51.65 \pm 0.83$ & $54.56 \pm 0.94$ & $58.38 \pm 1.15$ & $53.49 \pm 0.93$ & $54.08 \pm 0.99$ & $54.71 \pm 1.24$ \\
\hline 15 & $69.13 \pm 1.01$ & $67.34 \pm 0.92$ & $70.23 \pm 1.21$ & $69.43 \pm 1.16$ & $70.23 \pm 1.21$ & $67.69 \pm 0.81$ & $68.54 \pm 1.32$ & $66.67 \pm 0.85$ & $68.90 \pm 0.79$ \\
\hline 20 & $74.35 \pm 1.03$ & $71.45 \pm 1.50$ & $79.54 \pm 1.03$ & $77.45 \pm 1.25$ & $79.54 \pm 1.03$ & $84.92 \pm 1.09$ & $78.67 \pm 1.13$ & $78.07 \pm 1.24$ & $83.02 \pm 1.18$ \\
\hline 25 & $94.75 \pm 0.94$ & $93.31 \pm 0.74$ & $96.17 \pm 0.94$ & $94.36 \pm 0.82$ & $95.49 \pm 0.49$ & $96.89 \pm 1.27$ & $94.37 \pm 0.86$ & $97.68 \pm 0.96$ & $98.18 \pm 1.04$ \\
\hline
\end{tabular}


Comparison of drug release profiles of pure drug, marketed formulation and optimized formulation of captopril and HCTZ

The drug release profiles of optimized formulation were compared with that of respective pure drugs and their marketed formulations. Based on the results of dissolution profiles of captopril and HCTZ, the graphs were given in [Figures 9 and 10] respectively. The similarity factor was calculated as a part of model independent kinetics by comparing the drug release profiles of optimized compression formulation of HCTZ with that of marketed formulation of HCTZ. Similarity factor was calculated using the following equation:

$\mathrm{F}_{2}=50+\log \left\{\left[1+(1 / \mathrm{n}) \sum_{\mathrm{t}=1}{ }^{*} \mathrm{n}\left(\mathrm{R}_{\mathrm{t}}-\mathrm{T}_{\mathrm{t}}\right) 2\right]^{-0.5}\right\} * 100$

Where $R_{t}$ and $T_{t}$ are the cumulative percentage dissolved at each of the selected $n$ time points of reference and test product respectively

The $f$ value was found to be in the acceptable range of 50-100 according to US Food and Drug Administration (FDA).

\section{Fourier transform infrared spectroscopy (FTIR)}

FT-IR spectrometry was found to be most reliable technique for predicting the possible interaction between the drugs. The spectra was recorded for captopril, HCTZ, EC, pregelatinized starch, croscarmellose sodium, lactose, microcrystalline cellulose, talc individually and for optimized formulation using FTIR (bruker), model 10048657 Alpha-T., AT-001 opus software. The samples

\begin{tabular}{lc}
\multicolumn{2}{l}{ Table 15: Post-compression } \\
compression coated tablets \\
\hline Parameter & Value \\
\hline Weight variation & $750 \pm 0.231 \mathrm{mg}$ \\
Thickness & $7.5 \mathrm{~mm}$ \\
Hardness & $3 \mathrm{~kg} / \mathrm{cm}^{2}$ \\
Friability & $0.94 \%$ \\
Disintegration time of coat & $19 \mathrm{~s}$ \\
Wetting time & $25.92 \mathrm{~s}$ \\
Water absorption ratio & $20.5 \%$ \\
\hline
\end{tabular}

\section{Table 16: Correlation coefficients of the} formulation

\begin{tabular}{lcc}
\hline Kinetics & $\boldsymbol{R}^{2}$ of captopril & $\boldsymbol{R}^{2}$ of hydrochlorothiazide \\
\hline Zero order & 0.9728 & 0.9407 \\
First order & 0.9411 & 0.9917 \\
Higuchi model & 0.9870 & 0.9827 \\
Korsmeyer- & 0.9802 & 0.8979 \\
Peppas model & & \\
\hline
\end{tabular}

Table 17: Drug content of optimized formulation

\begin{tabular}{lccc}
\hline Name of the drug & $\begin{array}{c}\text { Label } \\
\text { claim }(\mathbf{m g})\end{array}$ & $\begin{array}{c}\text { Amount of } \\
\text { drug estimated } \\
\text { (mg) }\end{array}$ & $\begin{array}{c}\text { Percentage } \\
\text { of label } \\
\text { claim }\end{array}$ \\
\hline Captopril & 30 & 29.79 & 99.30 \\
Hydrochlorothiazide & 12 & 12.03 & 100.30 \\
\hline
\end{tabular}

were scanned from 1000 to $3500 / \mathrm{cm}$ and the obtained spectra were shown in [Figures 11-13].

\section{Differential scanning calorimetry (DSC)}

DSC was carried out to find out the presence of any interaction between the drug and excipients. Pure drugs (captopril, HCTZ)

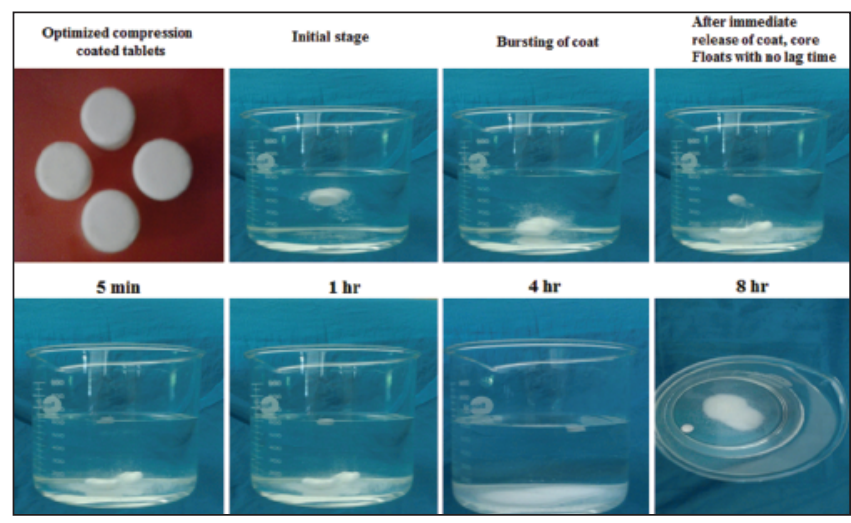

Figure 8: The images of compression coated formulation

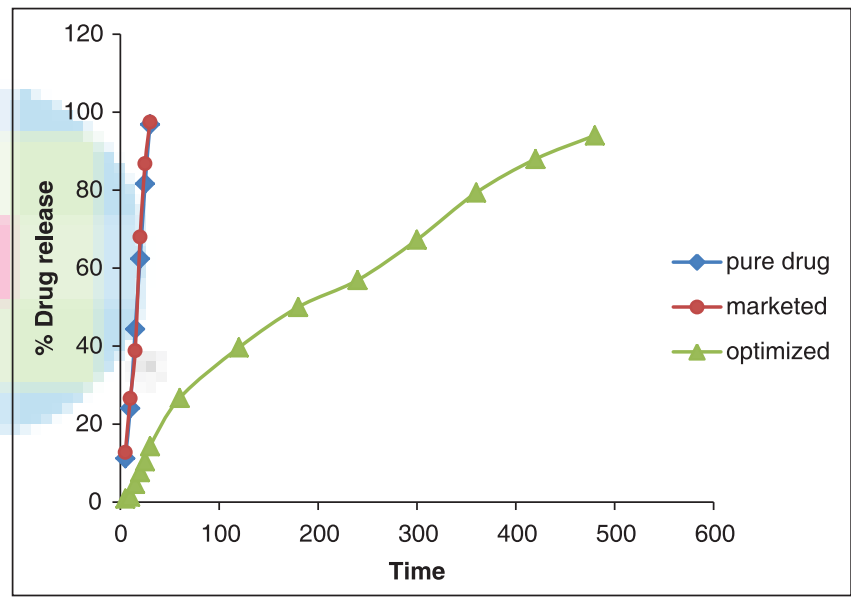

Figure 9: Zero order plot of pure drug, marketed and optimized compression coated formulation of captopril

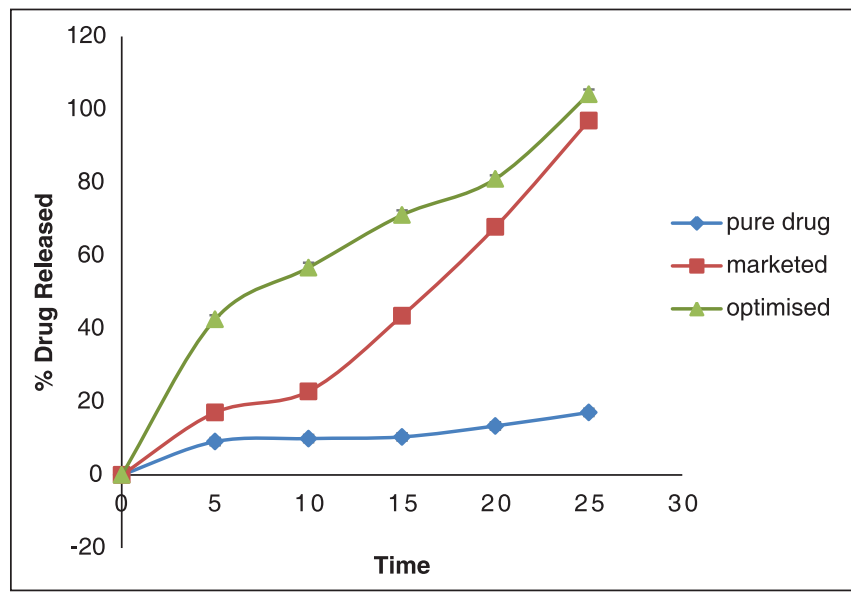

Figure 10: Zero order plot of pure drug, marketed and optimized compression coated formulation of hydrochlorothiazide 
and optimized formulation were subjected to DSC analysis. Samples were taken in the pierced DSC aluminum pan and scanned in the temperature range of $0-350^{\circ} \mathrm{C}$ for captopril pure drug, $0-290^{\circ} \mathrm{C}$ for $\mathrm{HCTZ}$ pure drug and $0-400^{\circ} \mathrm{C}$ for optimized formulation at a heating rate of $2^{\circ} \mathrm{C} / \mathrm{min}$ using differential thermal analyzer (Mettler Toledo) with STARe SW 9.01 Thermal Analysis Excellence software and the resulting thermo grams were shown in [Figures 14 and 15].

\section{Thermo gravimetric analysis (TGA)}

TGA is a technique in which the mass of a substance is monitored as a function of temperature or time as the sample specimen is subjected to a controlled temperature program in a controlled

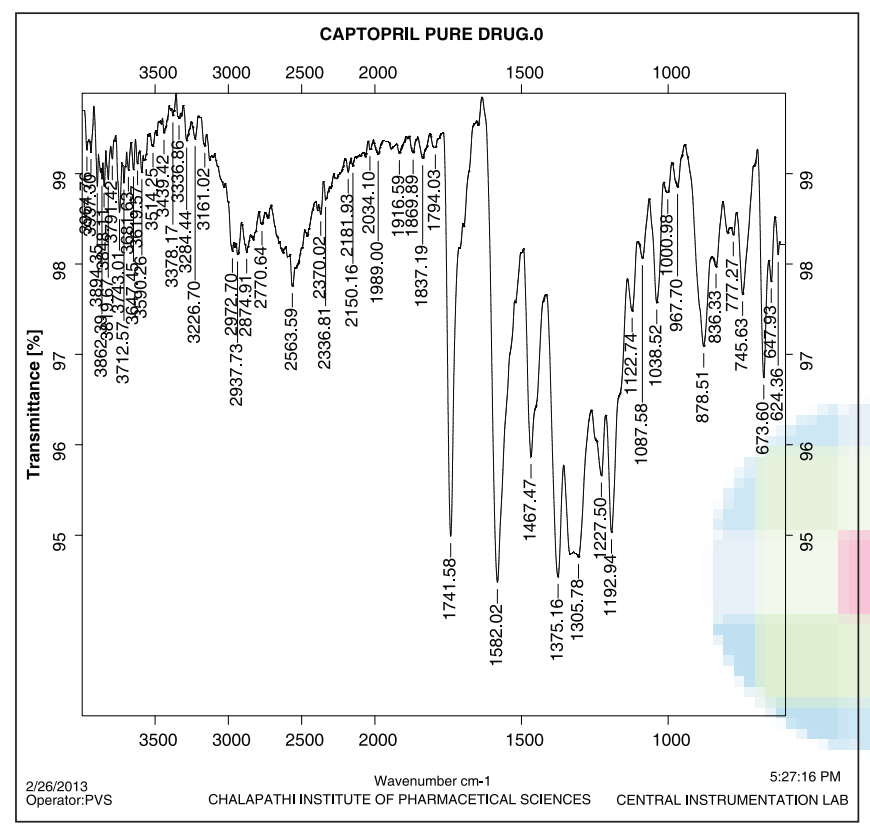

Figure 11: Fourier transform infrared spectroscopy spectra of captopril

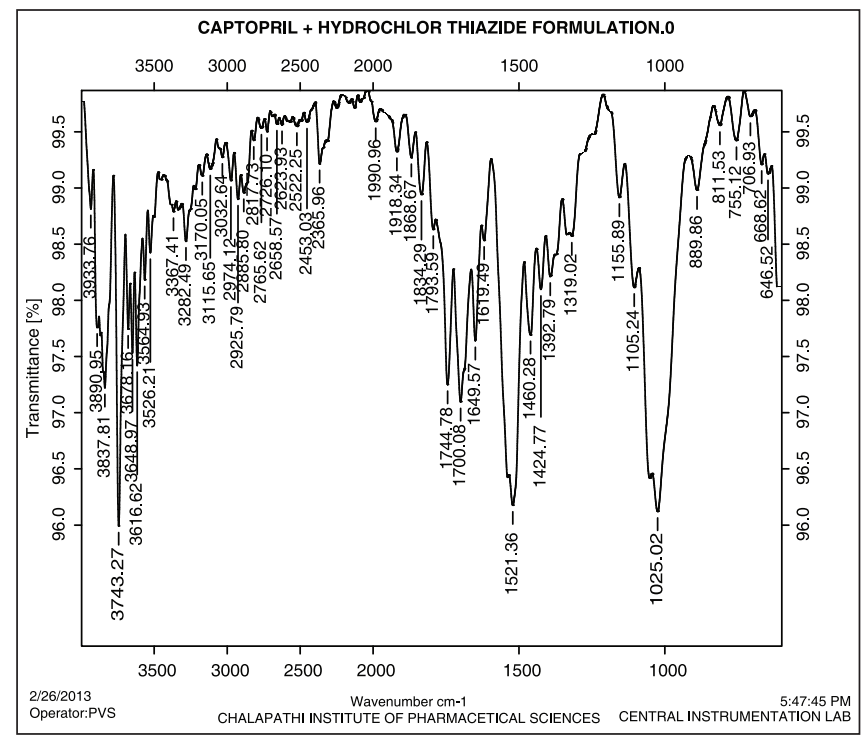

Figure 13: Fourier transform infrared spectroscopy spectra of optimized compression coated formulation atmosphere. TGA were performed for pure drugs and the optimized formulation using Inkarp TGA at a temperature range of $30-550^{\circ} \mathrm{C}$ at a heating rate of $2^{\circ} \mathrm{C} / \mathrm{min}$ in an aluminum pan using nitrogen gas. The results were shown in [Figures 16 and 17].

\section{RESULTS AND DISCUSSION}

Calibration curves were plotted for both captopril and HCTZ using UV spectrophotometric method. All the process was analyzed and based on obtained concentration and linearity it was found that obtained drug was pure and within the standards specified in IP.

\section{Evaluation of captopril core tablets}

The pre-compression results of captopril formulations indicates that $\mathrm{CF}_{2}, \mathrm{CF}_{4}, \mathrm{CF}_{6}, \mathrm{CF}_{8}$ formulations have acceptable flow

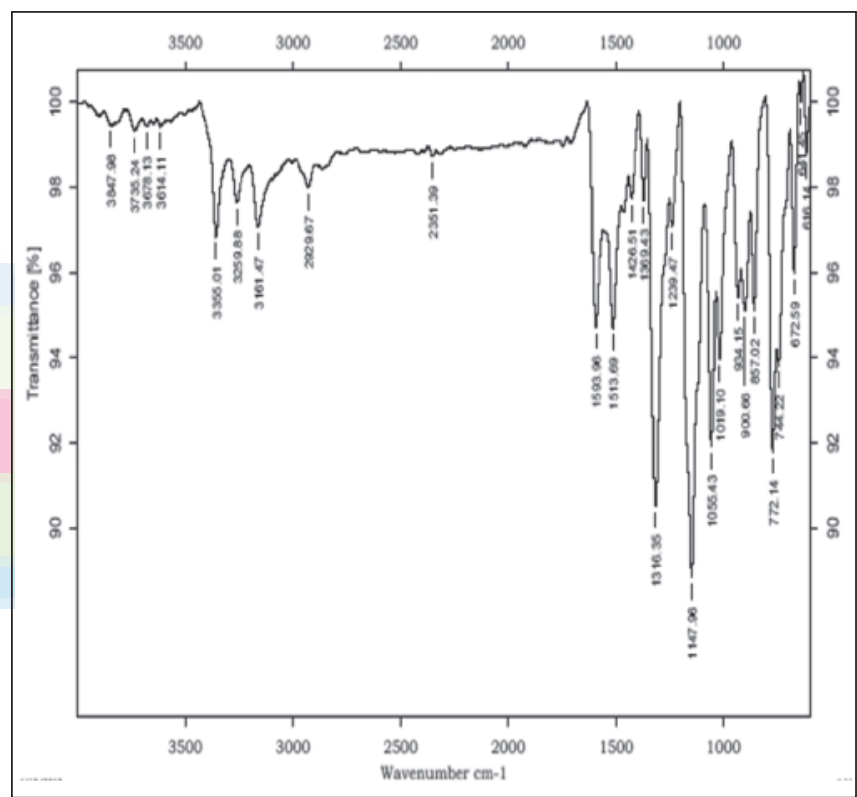

Figure 12: Fourier transform infrared spectroscopy spectra of hydrochlorothiazide

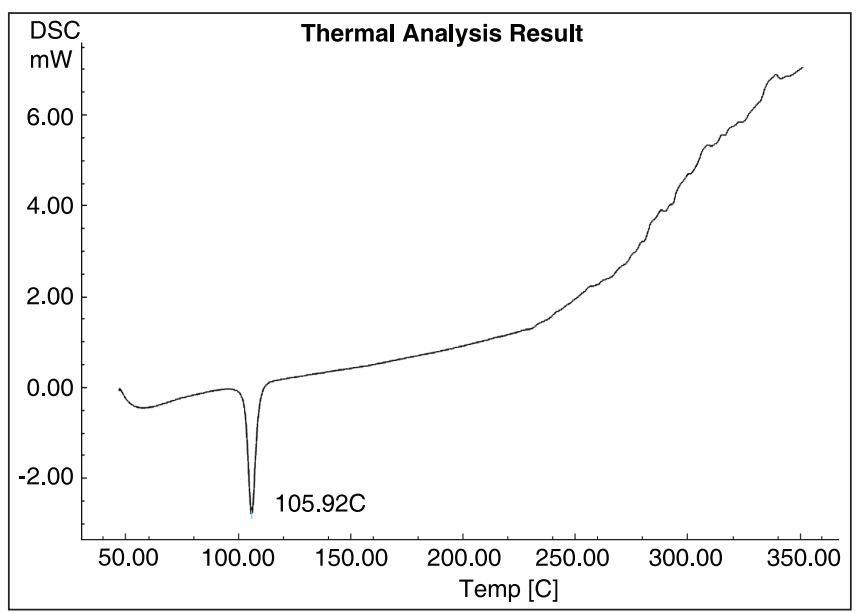

Figure 14: Differential scanning calorimetry of pure captopril 


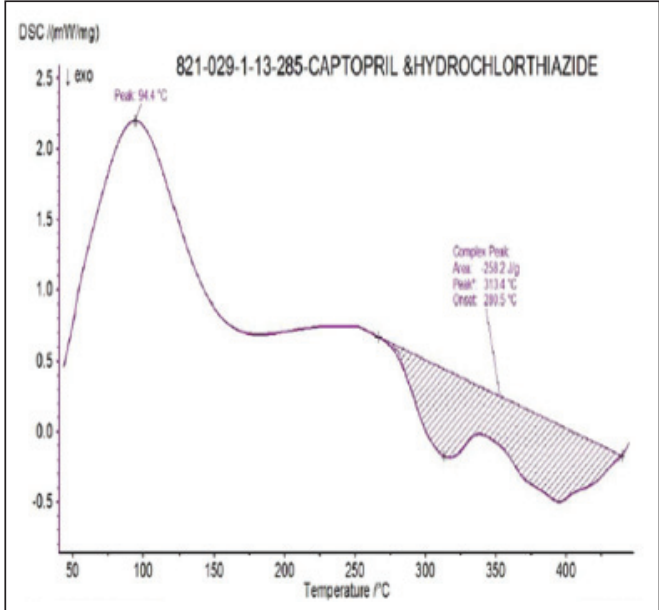

Figure 15: Differential scanning calorimetry of optimized compression coated formulation

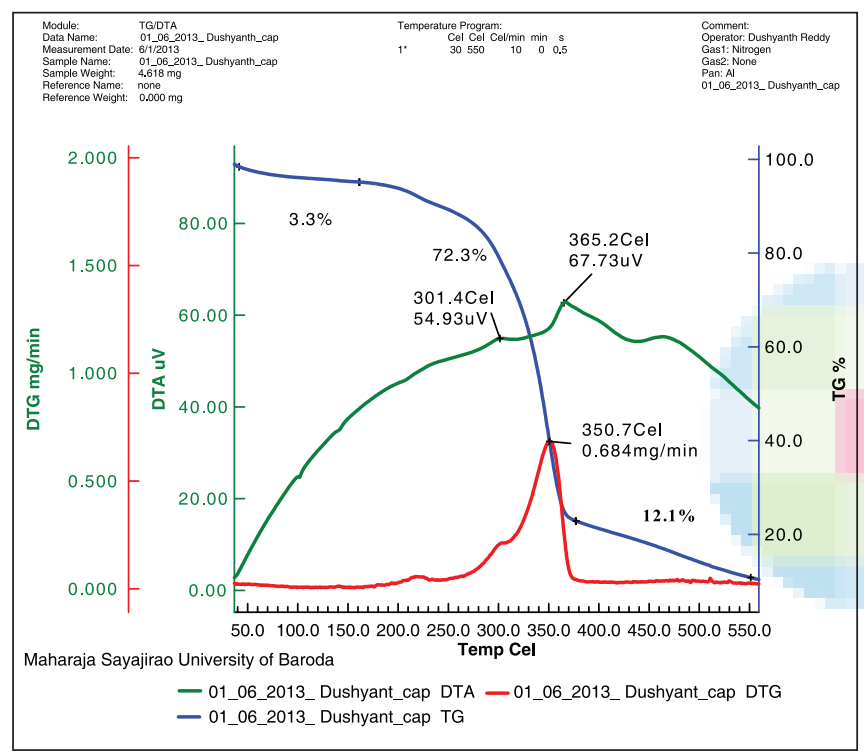

Figure 17: Thermo gravimetric analysis of optimized compression coated formulation, graph generated by V. Dushyanth reddy, Maharaja Sayajirao University of Baroda

properties. The post-compression results indicates that $\mathrm{CF}_{2}$, $\mathrm{CF}_{4}, \mathrm{CF}_{6}, \mathrm{CF}_{7}$ formulations have sufficient hardness and friability of all formulations was found to be $<1 \%$ which was within the range specified in IP. Among all the formulations $\mathrm{CF}_{2}$ formulation showed better floating time of $>8 \mathrm{~h}$, which fits for the present study. Some other formulations showed good floating tendency but got disintegrated. Among all the formulations, $\mathrm{CF}_{2}$ formulation showed better drug release profile of $97.42 \%$.

\section{Optimization of $2^{3}$ factorial design by statistical analysis}

The data obtained for response variables of buoyancy and $\mathrm{T}_{50 \%}$ were subjected to regression analysis using Microsoft excel for statistical assessment. According to the regression statistics of ANOVA for the response variable buoyancy, $R^{2}$ value was found

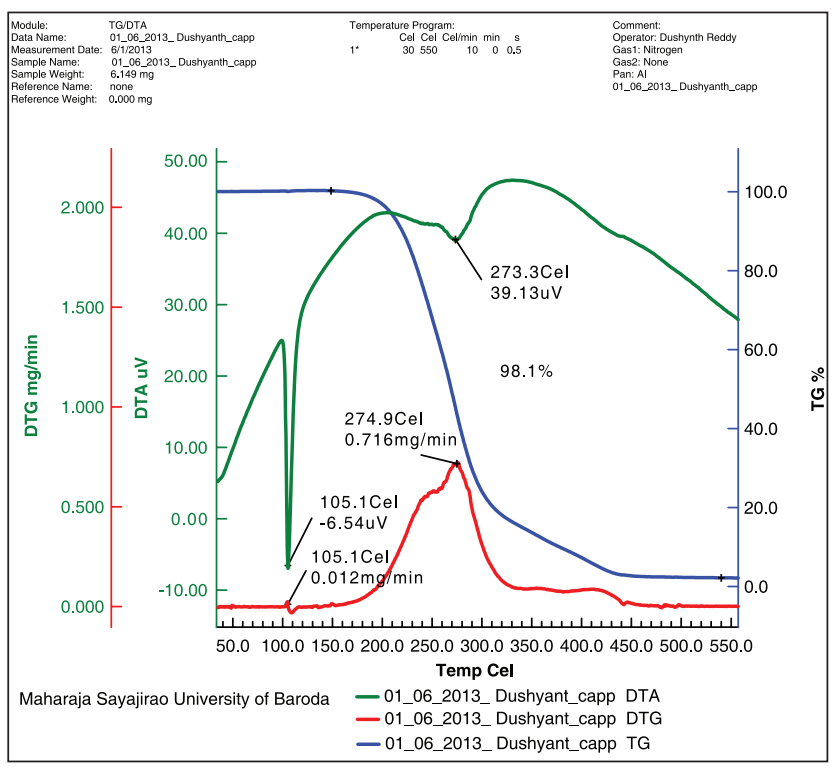

Figure 16: Thermo gravimetric analysis of pure captopril, graph generated by V. Dushyanth reddy, Maharaja Sayajirao University of Baroda

to be 0.786784 . From the ANOVA results it was observed that the $F$ value is much greater than significance $F$ value, which indicates that the null hypothesis can be rejected and thereby concludes that that this design has a significant effect on the prediction of considered level of factors on buoyancy. The regression coefficient of EC was found be positive which indicates that there is an increase in response of buoyancy with increase in level of concentration which was shown in the line fit plot of EC. The negative regression coefficients obtained for line fit plots of xanthan gum indicates that there is no significant effect on buoyancy and that of carbopol indicates that there is a decrease in response on buoyancy with an increase in corresponding levels of concentrations.

According to the regression statistics of ANOVA for response variable drug release $\left(\mathrm{T}_{50 \%}\right)$, the $R^{2}$ value was found to be 0.7403. From the ANOVA results, it was observed that the $F$ value is greater than significance $F$ value which indicates that the null hypothesis can be rejected and thereby concludes that that this design has a significant effect on the prediction of considered level of factors on drug release. The regression coefficient of EC was found be positive which indicates that there is an increase in response on drug release $\left(\mathrm{T}_{50 \%}\right)$ with increase in level of concentration which was shown in the line the line fit plot of EC. The negative regression coefficients obtained for line fit plots of xanthan gum indicates that there is no significant effect on drug release $\left(\mathrm{T}_{50 \%}\right)$ and that of carbopol indicates that there is a decrease in response of drug release $\left(\mathrm{T}_{50 \%}\right)$ with an increase in corresponding levels of concentrations.

The $P$ values for EC was found to be $<0.05$ which indicates that this factor has statistically significant effect on buoyancy and drug release $\left(\mathrm{T}_{50 \%}\right)$ and the presence of this factor at a high level 
is recommended in the formulation. The $P$ values of xanthan gum and carbopol were found to be $>0.05$ which indicates that these factors are not statistically significant and can be dropped out from the formulation.

From the statistical analysis it was proved that single factor EC has a significant dual action on buoyancy and drug release and this formulation can be used as optimized formulation for further work.

\section{Evaluation of HCTZ coat layer}

The pre-compression results of HCTZ formulations indicate that the $\mathrm{HF}_{9}$ formulation has good flow properties but all the formulations have acceptable flow properties. The postcompression results of HCTZ formulations indicate that $\mathrm{HF}_{8}, \mathrm{HF}_{9}$ formulations have sufficient hardness and all other formulations have acceptable hardness. Friability of all the formulations was $<1 \%$ which was within the range specified in IP. The rapid disintegration and wetting were seen in $\mathrm{HF}_{9}$ formulation containing $15 \%$ concentration of croscarmellose sodium as superdisintegrant rather than the formulations containing crospovidone and SSG.

$\mathrm{CF}_{2}$ was selected as optimized captopril core formulation as it complied with the requirements such as prolonged buoyancy and better drug release which was also proved by ANOVA and $\mathrm{HF}_{9}$ was selected as optimized HCTZ coat formulation as it complied with the requirements such as rapid disintegration time and better drug release.

\section{Evaluation of compression coated tablet}

The results showed weight variation of $750 \pm 0.231 \mathrm{mg}$. Thickness was found to be $7.5 \mathrm{~mm}$. Hardness and friability were found to be $3 \mathrm{~kg} / \mathrm{cm}^{2}$ and $0.94 \%$ respectively. The coat layer showed a rapid disintegration within $19 \mathrm{~s}$. The wetting time of formulation including core and coat was found to be $25.92 \mathrm{~s}$. The formulation showed water absorption ratio of $20.5 \%$. The results of all the evaluation tests for the optimized compression coated tablet were satisfactory and reproducible and were found to within the acceptable limits according to IP.

\section{In vitro drug release study}

The results of HCTZ coat layer of compression coated tablet showed that the Q value of HCTZ layer is achieved within 20 min following first order release whereas the $Q$ value of captopril was obtained at $6.5 \mathrm{~h}$ following Higuchi model. From the Q values it is proved that the rapid release HCTZ and slow release of captopril is achieved. The mechanism of drug release was analyzed using the exponent $n$ value of Peppas equation which showed an $n>0.90$ confirming case II transportation mechanism for drug release.

\section{Drug content}

Drug content of the optimized formulation was determined. The drug content was found to be $97.03 \%$ of label claim for captopril and that of $100.3 \%$ of label claim for HCTZ.
Comparison of drug release profiles of pure, marketed and optimized formulations of captopril and HCTZ

The drug release profiles of optimized formulation were compared with that of corresponding pure drug and marketed formulations. The results of captopril showed a drug release of $96.83 \%$ for pure drug within $30 \mathrm{~min}$ and $94.03 \%$ for optimized compression coated tablet for a period of $8 \mathrm{~h}$. The results of HCTZ showed a drug release of $17.09 \%$ for pure drug and $89.64 \%$ for marketed formulation.

The similarity factor was calculated as a part of model independent kinetics by comparing the drug release profiles of optimized compression formulation of HCTZ with that of marketed formulation of HCTZ. The similarity factor was found to be $71.2 \%$. The $f$ value was found to be in acceptable range of 50-100 according to US FDA.

\section{FTIR}

The IR spectra of pure captopril showed characteristic bands at 2874-2972/cm indicating C-H stretching. A prominent peak was obtained at $2770 / \mathrm{cm}$ indicating $\mathrm{SH}$ stretch. A peak was observed at $1741 / \mathrm{cm}$ indicating $\mathrm{C}=\mathrm{O}$ of $-\mathrm{COOH}$ group, $1582 / \mathrm{cm}$ indicating $\mathrm{C}=\mathrm{O}$ of Amide. Peaks were shown at range 1305$1375 / \mathrm{cm}$ indicating $\mathrm{OH}$ bending, $1227.5 / \mathrm{cm}$ indicating $\mathrm{C}-\mathrm{O}$ stretching, 1192/cm indicating CN stretching. The IR spectra of pure HCTZ showed characteristic bands at $1316.35-1369.43 / \mathrm{cm}$ indicating the $\mathrm{N}=\mathrm{C}$ stretch, Bands at $1379.1-1319.4 / \mathrm{cm}(\mathrm{N}=\mathrm{C}$ stretch), 1601.6-1589.8/cm (C = O stretch), 676.8/cm (aliphatic C-H band), 3362/cm (NH stretch), 1019-1166/cm (aromatic $\mathrm{C}=\mathrm{H}$ stretch), 1603/cm ( $\mathrm{N}=\mathrm{H}$ bend), 1473.3-1461.8/cm (S $=\mathrm{O})$ stretch. A prominent sharp peak was observed at $744 / \mathrm{cm}$ indicating the benzene ring deformation. Thus it is evident that all the characteristic peaks that were present in the spectra of pure drugs replicated in the same region in the spectra of compression coated tablet indicating that there is no significant interaction between the drugs and the polymers.

\section{DSC}

The DSC thermogram of captopril showed endothermic peak at $104.63^{\circ} \mathrm{C}$ which indicates the melting point of captopril and the DSC thermogram of HCTZ showed endothermic peak at $265.94^{\circ} \mathrm{C}$ indicating the melting point of $\mathrm{HCTZ}$ and exothermic peak at $285.70^{\circ} \mathrm{C}$. In DSC thermogram of compression coated tablet, a complex peak was obtained and peaks were obtained nearly at same temperatures as that of pure drugs indicating no significant interaction between the drugs and other excipients.

\section{TGA}

The TGA curve of pure captopril shows a sharp peak at $105.10^{\circ} \mathrm{C}$ and a small peak were observed in the TGA curve of compression coated formulation at $105-107^{\circ} \mathrm{C}$ which indicates the melting point of captopril. The peak of onset of decomposition was found at $274.9^{\circ} \mathrm{C}$ in TGA curve of pure captopril whereas the TGA curve of compression coated formulations showed the corresponding peak at $350.7^{\circ} \mathrm{C}$. It was observed that weight loss 
of optimized compression coated formulation was found to be $72.3 \%$ which is less when compared to pure drug showing $98.1 \%$ weight loss, indicating that the formulation is more stable than the pure drug.

\section{CONCLUSION}

The present study was targeted to develop sustained release floating formulation of captopril compression coated with gastric dispersible HCTZ layer for effective treatment of hypertension in non-dipping hypertensive patients. To prepare sustained release floating tablets various polymers were screened among which EC was selected as the suitable polymer. To formulate rapidly disintegrating coat layer various superdisintegrants were screened among which croscarmellose was chosen as a suitable superdisintegrant. The present study succeeded in maintaining the drug concentration in long term treatment of captopril and short term treatment of HCTZ. The multiple regression analysis (ANOVA) results obtained clearly indicate that EC is a better polymer for the formulation of sustained release floating tablets of captopril. The present study succeeded in obtaining both better release profile of drug and enhancement in buoyancy rate by using a single polymer (EC). Therefore the present formulation can be scaled up for the effective treatment of non-dipping hypertensive patients. Hence, this formulation advantageous in terms of cost-effectiveness decreases the bio burden and binary action of a single polymer.

\section{ACKNOWLEDGMENTS}

The authors are grateful to V. Dushyanth Reddy, Maharaja Sayajirao University of Baroda, India for thermogravimetric instrumental facilities and technical support. Authors are highly thankful to Nishka Labs, Hyderabad, India for DSC studies and for Chalapathi Institute of Pharmaceutical Sciences, Guntur, Andhra Pradesh, India for FTIR facilities.

\section{REFERENCES}

1. Tsioufis C, Andrikou I, Thomopoulos C, Petras D, Manolis A, Stefanadis C. Comparative prognostic role of nighttime blood pressure and nondipping profile on renal outcomes. Am J Nephrol 2011;33:277-88

2. Hansen TW, LiY, Boggia J, Thijs L, Richart T, Staessen JA. Predictive role of the nighttime blood pressure. Hypertension 2011;57:3-10.

3. Flack JM. Maximising antihypertensive effects of angiotensin II receptor blockers with thiazide diuretic combination therapy: Focus on irbesartan/hydrochlorothiazide. Int J Clin Pract 2007;61:2093-102.

4. Kalra S, Kalra B, Agrawal N. Combination therapy in hypertension: An update. Diabetol Metab Syndr 2010;2:44.

5. Frank J. Managing hypertension using combination therapy. Am Fam Physician 2008;77:1279-86.

6. Dollery C. Therapeutics Drugs. New York: Churchill Livingstone; 1999. p. c38-43.

7. Ferguson RK, Turini GA, Brunner HR, Gavras H, McKinstry DN. A specific orally active inhibitor of angiotensin-converting enzyme in man. Lancet 1977;1:775-8.

8. Nur AO, Zhang JS. Captopril floating and/or bioadhesive tablets: Design and release kinetics. Drug Dev Ind Pharm 2000;26:965-9.

9. Anaizi $\mathrm{NH}$, Swenson C. Instability of aqueous captopril solutions. Am J Hosp Pharm 1993;50:486-8.

10. Trissel LA, Trissel S. Stability of Compounded Formulations. J Am Pharm Assoc. 2000. p. 444.

11. Leon L, Herbert LA, Joseph KL. The Theory and Practice of Industrial Pharmacy. $3^{\text {rd }}$ ed. Journal of Chemical and Pharmaceutical sciences 1991:430-56.

12. James WA. Expandable gastric retention device. 2004; US Patent US2004/0219186A1.

13. Satoskar RS, Bhandakar SD, Ainapure SS. Pharmacology and Pharmacotherapeutics. $17^{\text {th }}$ ed. Mumbai: Popular Prakashan; 2001. p. 353-449.

How to cite this article: Sirisha PL, Babu GK, Babu PS.
Conceptuation, formulation and evaluation of sustained release
floating tablets of captopril compression coated with gastric
dispersible hydrochlorothiazide using $2^{3}$ factorial design. Int J
Pharma Investig 2014;4:77-87.
Source of Support: Nil. Conflict of Interest: None declared.

\section{Author Help: Online submission of the manuscripts}

Articles can be submitted online from http://www.journalonweb.com. For online submission, the articles should be prepared in two files (first page file and article file). Images should be submitted separately.

1) First Page File:

Prepare the title page, covering letter, acknowledgement etc. using a word processor program. All information related to your identity should be included here. Use text/rtf/doc/pdf files. Do not zip the files.

2) Article File:

The main text of the article, beginning with the Abstract to References (including tables) should be in this file. Do not include any information (such as acknowledgement, your names in page headers etc.) in this file. Use text/rtf/doc/pdf files. Do not zip the files. Limit the file size to $1024 \mathrm{~kb}$. Do not incorporate images in the file. If file size is large, graphs can be submitted separately as images, without their being incorporated in the article file. This will reduce the size of the file.

3) Images:

Submit good quality color images. Each image should be less than $\mathbf{4 0 9 6} \mathbf{~ k b ~ ( 4 ~ M B ) ~ i n ~ s i z e . ~ T h e ~ s i z e ~ o f ~ t h e ~ i m a g e ~ c a n ~ b e ~ r e d u c e d ~ b y ~ d e c r e a s - ~}$ ing the actual height and width of the images (keep up to about 6 inches and up to about $1800 \times 1200$ pixels). JPEG is the most suitable file format. The image quality should be good enough to judge the scientific value of the image. For the purpose of printing, always retain a good quality, high resolution image. This high resolution image should be sent to the editorial office at the time of sending a revised article.

4) Legends:

Legends for the figures/images should be included at the end of the article file. 